\title{
TRANSITIONING ARCHITECTURAL PEDAGOGY INTO THE VIRTUAL ERA VIA DIGITAL LEARNING METHODS
}

\author{
Tatiana Estrina, Alvin Huang, Vincent Hui, \& Kristen Sarmiento \\ Department of Architectural Science, Ryerson University (Canada)
}

\begin{abstract}
In an age of physical separation, a new pedagogical paradigm was established via the integration of pre-recorded videos, video conferencing, and online assessments to become hallmarks of the "new normal". In architectural education, the hands-on learning methodologies were suddenly compromised, challenging design pedagogy to reconfigure how students integrate collaborative design, studio culture, and develop analog skills into virtual learning. This prompted the question, how can architecture be effectively taught and experimentally explored through distanced and virtual means? The recent COVID-19 pandemic has disrupted this pedagogical environment and extinguished the opportunity of accessioning collaborative facilities considering recent distancing parameters. Conducting a literature review on experiences of virtual teaching in the realm of architecture, the paper explores scenarios, surveys, and adaptations to an unprecedented full online architecture studio. The paper showcases a series of teaching modifications that prove to be useful in maintaining and improving student engagement and performance in virtual architectural pedagogy.
\end{abstract}

Keywords: Architectural education, pedagogy, remote learning.

\section{Introduction}

After the declaration of the COVID-19 pandemic by World Health Organization (WHO) on March 11, 2020, architectural education pivoted towards a 'new normal' (Adhanom, 2020). With an unprecedented situation for education delivery, institutions enacted strategies for virtual schooling and improve on creating an efficient system for both students and teachers in trying times. The abrupt transition to online education proved difficult, especially as architecture programs are heavily reliant on the social studio setting and resources associated with it. From the initial reaction from students of isolation, disconnect, and disinterest to the difficulties experienced by faculty in communication, retention of engagement, and assessment models. Educators and institutions have begun to seek, develop, and enact strategies for virtual schooling to reduce issues and take advantage of possibilities. Through the research gathered from a keyword search literature review in combination with case studies conducted at the largest architecture school in Canada (Estrina et al., 2021; Hui et al., 2020), this paper provides an in-depth examination of the challenges and opportunities emergent in virtual architectural education.

\section{Methodology}

To review the various distant teaching methodologies implemented by architecture institutions globally, a literature review was conducted to gather peer-reviewed papers recounting the actions professors and instructors have taken to implement effective architectural education through results in students' academic success and positive social interactivity. A literature review on emergent responses to this condition was developed using a range of current publications using keyword search terms including "architecture education during pandemic", "remote design education", "online education during COVID-19 pandemic". Resulting papers stemmed from pedagogical discourse of numerous disciplines including architecture, interior design, traditional art schools, and engineering programs from around the globe. The research was comprised primarily of case studies and surveys evaluating student and faculty response to institutions' strategies to virtual delivery. In addition to the literature review, a parallel case study was conducted at Canada's largest architecture program, assessing the successes of the techniques and opportunities for experimental learning in virtual environments (Estrina et al., 2021; Hui et al., 2020). In relation to architectural pedagogy, a collection of software used for design collaboration, discourse, and research are gathered and examined in their effectiveness within virtual architectural curriculums.

\section{Results}

The rapid adoption of virtual learning in the disciplines architecture and design has been met with varied levels of success. Architecture programs translating virtually becomes a larger challenge, with 
the core component of design studio relying on social interactivity for constructive feedback which traditionally has been stimulated by habiting the physical studio environment (Jandrić et al., 2020). The literature review (Table 1) gathers multiple perspectives from institutions worldwide to observe common challenges, strategies, and resolutions in the transition to virtual learning. Compared to the preferable in-person learning, students easily lost interest in their online studies and were often stressed with the workloads that accompanied virtual learning (Kauser, 2020). This was a common finding amongst the surveys: another questionnaire conducted by Hananto revealed only $25 \%$ of students preferred online to physical classes (Hananto, 2020). Despite the mixed reactions to virtual learning, many online platforms used for student engagement received positive appraisals from students. Digital design platforms became the preferred tools for operations over analog drafting and model making due to the lack of access to resources (Hui et al., 2020). Online visualization and collaboration using software became even more ubiquitous in showcasing design ideas, in which students were required to develop not only their software skills, but their online presentation and organization skills as well (Estrina et al., 2021; Hui et al., 2020).

Table 1. Summary of results from literature studied.

\begin{tabular}{|c|c|c|c|c|}
\hline Authors/Paper & $\begin{array}{l}\text { Success of Virtual } \\
\text { Delivery }\end{array}$ & Challenges Identified & Benefits Identified & Software Used \\
\hline Ahmed K. & $\begin{array}{l}\text { The proposed method is } \\
\text { to allow for remote } \\
\text { learning to be more } \\
\text { efficient }\end{array}$ & Retaining student engagement & $\begin{array}{l}\text { Improved grasp of } \\
\text { spatial environments; } \\
\text { Virtual site visits } \\
\text { safer, inexpensive, } \\
\text { and expansive }\end{array}$ & $\begin{array}{l}\text { Revit, ClassVR, Microsoft } \\
\text { Teams, HoloLens, Magic } \\
\text { Leap One }\end{array}$ \\
\hline $\begin{array}{l}\text { Alhefnawi \& } \\
\text { Afify, } 2021\end{array}$ & $\begin{array}{l}\text { More failures in } \\
\text { web-based learning } \\
\text { compared to traditional } \\
\text { methods }\end{array}$ & $\begin{array}{l}\text { Malpractice during exams, lack } \\
\text { of interaction, increased failure } \\
\text { rates }\end{array}$ & $\begin{array}{l}\text { Higher grades } \\
\text { achieved, older } \\
\text { students more } \\
\text { independent }\end{array}$ & Blackboard, Zoom \\
\hline Brzezicki, M & $\begin{array}{l}70 \% \text { agree groupwork } \\
\text { led to effective } \\
\text { communication, } 76.6 \% \\
\text { enjoyed workshops, short } \\
\text { lectures }\end{array}$ & $\begin{array}{l}\text { Mental stress, internet } \\
\text { challenges, data limits, less } \\
\text { student-lecturer interaction, } \\
\text { sketching limitations with } \\
\text { mouse }\end{array}$ & $\begin{array}{l}\text { Remote learning is } \\
\text { more time efficient, } \\
\text { Increased attendance } \\
(92 \% \text { instead of } 70 \% \\
\text { previously) }\end{array}$ & $\begin{array}{l}\text { Moodle, Kahoot, Socrative, } \\
\text { Google Docs } \\
\text { (presentations), Zoom, } \\
\text { Microsoft Teams }\end{array}$ \\
\hline $\begin{array}{l}\text { Casakin \& } \\
\text { Wodehouse }\end{array}$ & & $\begin{array}{l}\text { Fixation on design, difficulty } \\
\text { emulating traditional studio } \\
\text { environment, creative } \\
\text { discussion difficult }\end{array}$ & $\begin{array}{l}\text { Improved spatial } \\
\text { perception, using } \\
\text { abstract design tasks } \\
\text { freed imagination }\end{array}$ & $\begin{array}{l}\text { Virtual and augmented } \\
\text { reality }\end{array}$ \\
\hline Ceylan et. al & $\begin{array}{l}\text { Results vary amongst the } \\
\text { first, second, third, and } \\
\text { fourth years: first years } \\
\text { are more positive about } \\
\text { the situation }\end{array}$ & $\begin{array}{l}\text { Travel restrictions, adaptation } \\
\text { to new working spaces, } \\
\text { psychological issues }\end{array}$ & $\begin{array}{l}\text { Development of } \\
\text { presentation skills, } \\
\text { access to lecture } \\
\text { recordings }\end{array}$ & $\begin{array}{l}\text { Adobe Connect, Sketchup, } \\
\text { Lumion, AutoCAD, Google } \\
\text { Earth, Google Maps, } \\
\text { Google Hangouts, Skype }\end{array}$ \\
\hline Hananto, B & $\begin{array}{l}75 \% \text { students preferred in } \\
\text { person learning, }>50 \% \\
\text { found online learning } \\
\text { more challenging }\end{array}$ & $\begin{array}{l}\text { Transition to remote education } \\
\text { was challenging for instructor } \\
\text { and students }\end{array}$ & $\begin{array}{l}\text { Less expensive, } \\
\text { Increased flexibility }\end{array}$ & Digital classroom platforms \\
\hline Hui et al., 2020 & & $\begin{array}{l}\text { Reduced social connectivity, } \\
\text { lack of peer support }\end{array}$ & $\begin{array}{l}\text { Worldwide } \\
\text { connectivity, } \\
\text { increased digital } \\
\text { fluency }\end{array}$ & $\begin{array}{l}\text { Miro, Zoom, Enscape, } \\
\text { Rhinoceros } 3 D, \text { Blogspot }\end{array}$ \\
\hline Ibrahim et. al & $\begin{array}{l}75 \% \text { of faculty support } \\
\text { teaching theory online } \\
65 \% \text { agreed that virtual } \\
\text { design education was } \\
\text { ineffective }\end{array}$ & $\begin{array}{l}\text { Faculty reported time } \\
\text { management and privacy } \\
\text { issues, psychological issues } \\
\text { (lack of boundary between } \\
\text { work and home), evaluation } \\
\text { tool and communication issues }\end{array}$ & $\begin{array}{l}\text { According to the } \\
\text { faculty, history and } \\
\text { theory courses were } \\
\text { as effective as } \\
\text { traditional teaching }\end{array}$ & $\begin{array}{l}\text { Zoom, Microsoft Teams, } \\
\text { Facebook Messenger }\end{array}$ \\
\hline $\begin{array}{l}\text { Iranmanesh, } \\
\text { Aminreza } \\
\text { Onur, Zeynep }\end{array}$ & $\begin{array}{l}\text { Overall positive reviews } \\
\text { for virtual design studios }\end{array}$ & Lack of peer learning & $\begin{array}{l}\text { Accessibility to } \\
\text { lecture recordings, } \\
\text { improvement in } \\
\text { software skills }\end{array}$ & $\begin{array}{l}\text { WhatsApp, Facebook, } \\
\text { YouTube, Skype, Google } \\
\text { Meet, AutoCAD, Sketchup }\end{array}$ \\
\hline Kauser, A. & $\begin{array}{l}\text { Faculty agreed that } \\
\text { teaching design studios } \\
\text { online was not effective }\end{array}$ & $\begin{array}{l}\text { Plagiarism, loss of student } \\
\text { interest, increased stress levels, } \\
\text { lack of self-motivation, } \\
\text { psychological and emotional } \\
\text { challenges, reduced design } \\
\text { quality, lack of access to } \\
\text { resources }\end{array}$ & $\begin{array}{l}\text { Students become } \\
\text { more independent, } \\
\text { students from multiple } \\
\text { institutions can } \\
\text { collaborate together }\end{array}$ & $\begin{array}{l}\text { Moodle, Eduwave, Big Blue } \\
\text { Button (BBB), Zoom, } \\
\text { Google Meet, Screencast-O- } \\
\text { Matic, Skype, Facebook, } \\
\text { YouTube, Instagram, } \\
\text { WhatsApp, Turnitin }\end{array}$ \\
\hline $\begin{array}{l}\text { Kristianova K. } \\
\text { \& Joklova V }\end{array}$ & $\begin{array}{l}\text { On-site research and trips } \\
\text { were not possible to } \\
\text { conduct }\end{array}$ & $\begin{array}{l}\text { On-site research abilities were } \\
\text { limited, Lack of ambiance and } \\
\text { atmosphere in virtual site visits }\end{array}$ & $\begin{array}{l}\text { Virtual site visits are } \\
\text { more affordable }\end{array}$ & $\begin{array}{l}\text { Google Suite, Google } \\
\text { Hangouts, Good Maps }\end{array}$ \\
\hline $\begin{array}{l}\text { Peimani, M. \& } \\
\text { Kamalipour, H. }\end{array}$ & & $\begin{array}{l}\text { Impaired student development, } \\
\text { Time zone incompatibility, } \\
\text { Inequality of access digital } \\
\text { resources }\end{array}$ & $\begin{array}{l}\text { Intrapersonal students } \\
\text { were more } \\
\text { comfortable, recorded } \\
\text { lectures more } \\
\text { inclusive }\end{array}$ & $\begin{array}{l}\text { Microsoft Teams, Learning } \\
\text { Central }\end{array}$ \\
\hline $\begin{array}{l}\text { Pregowska, } \\
\text { Et. al }\end{array}$ & $\begin{array}{l}\text { Dissatisfaction with } \\
\text { remote learning } \\
\text { increasing overtime }\end{array}$ & $\begin{array}{l}\text { Pandemic fatigue, lack of } \\
\text { physical contact with peers, } \\
\text { dissatisfaction with group work }\end{array}$ & $\begin{array}{l}\text { Flexibility and access } \\
\text { to remote courses, } \\
\text { virtual reality was } \\
\text { safer and less } \\
\text { expensive }\end{array}$ & $\begin{array}{l}\text { Microsoft Hololens, Magic } \\
\text { Leap One, AjnaLens, } \\
\text { AulaVR }\end{array}$ \\
\hline Spitz et. Al. & & $\begin{array}{l}\text { Lack of engagement, inability } \\
\text { to provide computer resources } \\
\text { to everyone in need, emotional } \\
\text { challenges, lack of privacy }\end{array}$ & $\begin{array}{l}\text { Improved attendance, } \\
\text { Excellent grades and } \\
\text { work }\end{array}$ & $\begin{array}{l}\text { Minecraft, Blender, Hubs, } \\
\text { eLearning platforms }\end{array}$ \\
\hline $\begin{array}{l}\text { Varma A. \& } \\
\text { Jafri M }\end{array}$ & $\begin{array}{l}33 \% \text { were satisfied with } \\
\text { remote learning, but not } \\
\text { satisfied with online } \\
\text { design studio }\end{array}$ & $\begin{array}{l}\text { Digital tools aren't widely used, } \\
\text { professors had difficulty } \\
\text { discussing ideas visually with } \\
\text { lack of hardware }\end{array}$ & $\begin{array}{l}\text { Remote learning } \\
\text { allows more } \\
\text { flexibility - less } \\
\text { distance barriers }\end{array}$ & $\begin{array}{l}\text { Zoom, Microsoft Teams, } \\
\text { WhatsApp, YouTube, } \\
\text { SlideShare }\end{array}$ \\
\hline
\end{tabular}




\section{Discussion}

Although remote learning has largely been integrated into architectural programs worldwide due to closures, lockdowns, and social distancing, there are numerous issues that emerge. These include reduced student interaction, the importance of feedback loops, absence of social engagement, difficulty with assessment, digital fluency, and technical issues. In order rectify and combat some of the emerging issues, the literature examined presents a number of best practices as well as opportunities for capitalizing on the format for enhanced learning.

\subsection{Feedback loops and communication pathways in virtual studio environments}

The virtual format creates somewhat of a disconnect between students and instructors, especially in lecture courses where the education becomes very one-sided. Where in a typical in-person classroom students are able to pose questions and chat with professors individually with relative ease, web-based education makes this challenging as the latency is responses becomes staged and less natural in pacing (Alhefnawi \& Afify, 2021). Conversations become either very public or require students and instructor to connect outside of class hours, which is not always a possibility. Thus, the establishment of efficient feedback exchange and communication amongst students and lecturers should be explored as a priority (Casakin \& Wodehouse, 2021). Whether via the creation of office hours outside of class time, messaging channels for questions, or rapid replies to emails, instructors must invest more time in providing timely and sufficient support for students in web-based instruction (Alhefnawi \& Afify, 2021). Studio courses also pose a multitude of other communication issues affecting collaboration between instructors and students. The virtual communication methods which are typical for studio courses become challenging, especially for professors that are used to hand drawing ("How Virtual Learning Is Impacting Studio Time for Architecture Courses," 2021). Experimentation with both alternative drawing and brainstorming software, such as Miro, in conjunction with additional digital tools including drawing tablets can aid in bridging this disparity (Hui et al., 2018).

\subsection{Evaluation and assessment}

When evaluating student work conducted remotely, many faculty members experienced issues with evaluation tools and methods (Ibrahim et al., 2020). In addition to malpractice during exams, plagiarism and cheating became more prevalent with online education, as the lack of monitoring and social presence eliminated barriers and social pressures against such behaviors (Alhefnawi \& Afify, 2021; Kauser, 2020). In order to avoid such issues, exam-based evaluations may be conducted in open-book formats or replaced with project and paper-based evaluation methods. Conversely, proverbial architectural juries prove to be an opportunity for enhancement when transitioned to the online environment. Despite some limitations, virtual juries gave students more control over the content being viewed as any given moment, causing students to prefer virtual over physical reviews (Iranmanesh \& Onur, 2021). In addition, the digitally-hosted reviews allow for more diverse jury compositions, with the possibility of participation of professionals and academics from around the world (Hui et al., 2020; Iranmanesh \& Onur, 2021). Students also appreciated the ability for reviews to be recorded for re-checking, allowing for deeper learning (Iranmanesh \& Onur, 2021). In fact, student success has proven to be independent of teaching mode, however digital delivery methods are more challenging for high-grade students and those lacking digital design skillsets (Alhefnawi \& Afify, 2021).

\subsection{Attentiveness and student engagement}

Despite the increase in attendance, many educators found it challenging to retain students' attention and create engaging environments when teaching remotely (Brzezicki, 2020). Faculty found lectures to be lonely, with a loss of student interest and attendance despite efforts taken to engage the group, leading to a very dissatisfying experience for both parties (Jandrić et al., 2020; Kauser, 2020; Spitz et al., 2020). Some techniques outlined in order to maintain student interest involve shorter, more compact classes alongside small group discussions (Brzezicki, 2020). This approach allows for a less lengthy and convoluted delivery of the content while also providing increased social connectivity among students, forcing them to engage (Brzezicki, 2020). Furthermore, the incorporation of interactive activities including virtual field trips, proved to increase overall interest and engagement in projects as well as a deeper understanding of context (Hui et al., 2020; Kristianova \& Joklova, 2020). Virtual networks can be used to expose students to a variety of different perspectives, both regionally and internationally, thus the invitation of guest lecturers and reviewers aids in diversifying the experience (Hui et al., 2020; Spitz et al., 2020).

\subsection{Social connectivity}

Prior to the pandemic-driven shift to digital learning, studio was at the center of architectural education, with students using the space to work on their project while also receiving advice and criticism from professors and other students ("How Virtual Learning Is Impacting Studio Time for Architecture 
Courses," 2021). While some students found it easier to communicate solely through virtual means, the lack of direct eye contact, face-to-face communication, and active engagement proved to be detrimental to student's productivity (Peimani \& Kamalipour, 2021). To be around other students allowed them to maintain high energy and spirits, which was found to be lacking in the isolated environment of virtual learning ("How Virtual Learning Is Impacting Studio Time for Architecture Courses," 2021). Peimani and Kamalipour identified the development of professional, communication, and practical skills as critical challenges that emerge in remote learning (Peimani \& Kamalipour, 2021). Despite students' dissatisfaction with graded group work, the inclusion of smaller, ungraded in-class group assignments can stimulate interaction among students, by reducing communication circles and allowing for a more intimate space (Pregowska et al., 2021). Many educators began to conduct studio desk reviews in small groups in order to stimulate peer-to-peer student interaction. As an importance is placed on the sharing and discussion of student projects in architectural education, an emphasis remains on the circulation of in progress and final work, be it via publications, websites, events, blogs, or social media (Hui et al., 2020). These platforms can additionally serve to generate interaction and connections among the students themselves, with the use of blogs proving to be especially effective (Hui et al., 2020).

\subsection{Digital fluency and technical effectiveness}

Upon adoption of the virtual learning model, capitalization on digital learning has been identified as an opportunity for student development. As students are, "native speakers of digital technologies and virtual space", they are equipped for the rapid adoption of new software and toolsets which are becoming more desirable in the industry (Iranmanesh \& Onur, 2021). A mixture of digital learning conditions and difficulties allows for students to develop a variety of skillsets more effectively and collaboratively (Estrina et al., 2021). Additional avenues of expansion of digital fluency involve the inclusion of extended realities mainly virtual reality (VR), augmented reality (AR), and mixed reality (MR), into architectural teaching. The integration of these technologies into digital learning provides students with enhanced virtual opportunities and experiences, both for the learning of lecture-based content and for design work (Ahmad et al., 2020; Aydin \& Aktaş, 2020; Estrina et al., 2021; Hui et al., 2020). To aid student comprehension of spatial relationships, which proved to be a deficiency in virtual education, real-time rendering software visualization using extended realities were able to mitigate this gap (Ceylan et al., 2020; Estrina et al., 2021; Hui et al., 2020). While these environments cannot replace in-person learning, they give agency to students to convey design ideas virtually whilst improving software abilities (Ahmed, 2020). Building information modelling (BIM) software were also widely utilized, bridging disciplines via robust platforms, and providing extensive collaboration features for student (Ahmed, 2020).

However, the inevitable involvement of technologies in virtual education uncovers additional longstanding challenges in contemporary design education. Equal access to resources, software, and hardware proved to be an issue in many developing countries, and providing support is particularly important in ensuring students have equal opportunities for success (Alhefnawi \& Afify, 2021; Varma \& Jafri, 2020). Additionally, provisions for contingency plans in case of technical issues are critical in maintaining successful classes or studios (Alhefnawi \& Afify, 2021). In addition, provision of various training sessions on the assorted software, both for instructors to improve teaching quality and for students to aid in graphic and verbal presentations, is beneficial in reducing technological barriers (Ibrahim et al., 2020). The development of quick and efficient response strategies have emerged as a key to the successful conduction of virtual education and the response to crisis (Al-Taweel et al., 2020).

\section{Conclusion}

While the global pandemic has enacted a myriad of parameters redefining education delivery, the use of online platforms has become paramount to keep students connected and advance methodologies pedagogy. With mixed success, architectural pedagogy was transitioned into the virtual, encountering successes and challenges. Some notable difficulty areas included evaluation, assessment models, and feedback loops; reduced social connectivity; lack of attentiveness and student engagement; and absence of digital fluency and technical effectiveness. A greater effort from faculty in order to establish communication pathways and increase engagement in the virtual lecture hall, in combination with additional instructional software sessions and support, begin to resolve some of these pitfalls. Instead, academics can capitalize on the opportunities emergent in virtual education, namely diverse guest and jury composition, virtual travel, incorporation of extended realities, and the wider reach of education. As countries begin to reopen, conversations have begun around a blend-type of course delivery, where alongside the in-person education additional synchronous virtual meetings are provided (Ibrahim et al., 2020). This approach can harness the benefits of remote online learning while maintaining the social connectivity that this instructional method currently lacks. Despite the passing nature of the COVID-19 pandemic, the effects of the resulting web-based pedagogy are sure to be lasting in architectural education. 


\section{References}

Adhanom, T. (2020). WHO Director-General's opening remarks at the media briefing on COVID-19 - 11 March 2020. World Health Organization. https://www.who.int/directorgeneral/speeches/detail/who-director-general-s-opening-remarks-at-the-media-briefing-on-covid19---11-march-2020

Ahmad, L., Sosa, M., \& Musfy, K. (2020). Interior design teaching methodology during the global COVID-19 pandemic. Interiority, 3(2), 163-184. https://doi.org/10.7454/in.v3i2.100

Ahmed, K. G. (2020). Augmented reality in remote learning: A proposed transformative approach for building construction education. Proceedings of the International Conference on E-Learning, ICEL, 2020-Decem, 115-120.

Al-Taweel, D., Al-Haqan, A., Bajis, D., Al-Bader, J., Al-Taweel, A. R. M., Al-Awadhi, A., \& Al-Awadhi, F. (2020). Multidisciplinary academic perspectives during the COVID-19 pandemic. In International Journal of Health Planning and Management (Vol. 35, Issue 6, pp. 1295-1301).

Alhefnawi, M., \& Afify, H. (2021). Exam Grades in Architecture Classes : A Comparative Assessment of Before and During COVID-19 Pandemic Modes of Teaching and Learning. January.

Aydin, S., \& Aktaş, B. (2020). Developing an Integrated VR Infrastructure in Architectural Design Education. Frontiers in Robotics and AI, 7(October). https://doi.org/10.3389/frobt.2020.495468

Brzezicki, M. (2020). Strengths and weaknesses of architectural education on-line classes conducted during COVID-19. World Transactions on Engineering and Technology Education, 18(4), 381-386.

Casakin, H., \& Wodehouse, A. (2021). A systematic review of design creativity in the architectural design studio. Buildings, 11(1), 1-19. https://doi.org/10.3390/buildings11010031

Ceylan, S., Şahin, P., Seçmen, S., Somer, M. E., \& Süher, K. H. (2020). An evaluation of online architectural design studios during COVID-19 outbreak. Archnet-IJAR, 15(1), 203-218.

Estrina, T., Hui, V., \& Ma, L. (2021). The digital design build. PROJECTIONS, Proceedings of the 26th International Conference of the Association for Computer-Aided Architectural Design Research in Asia (CAADRIA), 2, 41-50.

Hananto, B. A. (2020). Explorations of design by digital \& remote education. Architecture \& Design (IMADe), l(October), p-ISSN. http://eprosiding.std-bali.ac.id/index.php/imade

How virtual learning is impacting studio time for architecture courses. (2021). In The Shorthorn (pp. 1-2).

Hui, V., Estrina, T., \& Huang, A. (2020). Creative Connections: Maintaining Studio Culture In An Age Of Physical Separation. ICERI2020 Proceedings, 5082-5089. https://doi.org/10.21125/iceri.2020.1105

Hui, V., Estrina, T., Zhou, G., Lee, S., \& Kinuthia, V. (2018). Architectural Accessibility And Pedagogy Via Virtual Reality. 1-13.

Ibrahim, A. F., Attia, A. S., Bataineh, A. M., \& Ali, H. H. (2020). Evaluation of the online teaching of architectural design and basic design courses case study: College of Architecture at JUST, Jordan. Ain Shams Engineering Journal, xxxx. https://doi.org/10.1016/j.asej.2020.10.006

Iranmanesh, A., \& Onur, Z. (2021). Mandatory Virtual Design Studio for All: Exploring the Transformations of Architectural Education amidst the Global Pandemic. International Journal of Art and Design Education, 40(1), 251-267. https://doi.org/10.1111/jade.12350

Jandrić, P., Hayes, D., Truelove, I., Levinson, P., Mayo, P., Ryberg, T., \& Monzó, L. D. (2020). Teaching in the Age of Covid-19. Postdigital Science and Education, 2, $1069-1230$.

Kauser, A. N. (2020). Rethinking architecture pedagogy in the era of pandemics. 1-6.

Kristianova, K., \& Joklova, V. (2020). on-Site Research, Excursions, and Field Trips in Architectural Education - Constraints in the Time of Covid-19. ICERI2020 Proceedings, 1(November), 5677-5682.

Peimani, N., \& Kamalipour, H. (2021). Online education and the covid-19 outbreak: A case study of online teaching during lockdown. Education Sciences, 11(2), 1-16. https://doi.org/10.3390/educsci11020072

Pregowska, A., Masztalerz, K., Garlińska, M., \& Osial, M. (2021). A worldwide journey through distance education - from the post office to virtual, augmented and mixed realities, and education during the covid-19 pandemic. Education Sciences, 11(3). https://doi.org/10.3390/educsci11030118

Spitz, R., González, J. R., Ugarte, S., Meythaler, A. Á., Abril, X. B., \& Idiáquez, J. M. (2020). Towards a "Better Normal ": Educational Experiences in Design in Latin America During the COVID-19 Pandemic. Strategic Design Research Journal, 13(03), 564-576.

Varma, A., \& Jafri, M. S. (2020). COVID-19 responsive teaching of undergraduate architecture programs in India: learnings for post-pandemic education. Archnet-IJAR, 15(1), 189-202. 